ROCZNIKI HUMANISTYCZNE

Tom LXVII, zeszyt $9-2019$

DOI: http://dx.doi.org/10.18290/rh.2019.67.9-4

MARIA KURPASKA

\title{
HOW TO CREATE A LANGUAGE \\ FOR THE WHOLE PEOPLE? ON THE CODIFICATION \\ OF PUTONGHUA PRONUNCIATION
}

\begin{abstract}
A bstract. The process of creating a modern national standard language for the whole of China has been long. It started in the beginning of the $20^{\text {th }}$ century, when it became clear that a common spoken tongue was needed to unite the Chinese people. Thus the concept of Guóyú — 'national language' - was created.

After the founding of People's Republic of China, the work was taken up anew, the standard was renamed Pŭtōnghuà — 'common speech.' Its pronunciation is based on the dialect of Beijing, the Mandarin dialects have been the source of lexicon, and grammar has been founded on "model works in báihuà."

But how exactly did the work on creating the new standard look like? This paper intends to show the process of codification of the pronunciation of what we now know as Pŭtōnghuà. How it was decided to choose the speech of Beijing as the starting point, how the work was carried out, and also how the standard is changing.
\end{abstract}

Key words: Putonghua; Mandarin; codification; language reform; phonetics; phonology.

The aim of this paper is to show the process of codification of the pronunciation of what we now know as Putonghua (Pŭtōnghuà 普通話). To create a standard language for a country as vast as China was a challenging task, undertaken by a few generations of linguists and politicians. Not all the decisions made by them were as obvious as may seem. The intention of the article is, among others, to show how it was decided to choose the speech of Beijing as the starting point, how the work was carried out, and also how the standard is changing.

Maria KurPaska, PhD - Adam Mickiewicz University in Poznań, Department of Oriental Studies; address for correspondence: ul. Grunwaldzka, 660-780 Poznań, email: kurpaska@amu. edu.pl; ORCID: https://orcid.org/0000-0001-8836-2855. 


\section{HISTORICAL BACKGROUND}

Creating a national standard for the whole of China was a long process, with roots in historical times. In the remote past, the language of superdialectal communication was known as yăyán 雅言 ('elegant speech' or 'correct speech'). It is a term used in reference to the language of communication between various states during the times of the Spring and Autumn Period (ca. 770-480 BC) and the Warring States Period (ca. 480-221 BC). It was based on the language of the capitals of Zhou dynasty, i.e. Xi' an and Luoyang, and it is essentially equivalent to Old Chinese. It is also known as tōngyǔ 通语 ('common tongue'), or zhèngyinn 正音 ('correct sounds') (cf. Dong 2014, 6 and 43; Chen 2015, 534; YUAN 2003, 17; LÜ 2002, 41-2). Some authors (cf. WANG and TsAI 2015, 559) even suggest, that yayan originated in the times of the legendary Xia Dynasty (ca. 2070-1600 BC).

Guānhuà 官话 ('language of officials (mandarins)') is a term which describes the language of communication used by the workers of the administration (cf. SHI 2016, 723; CHEN 2004, 7-13). Guānhuà was always connected with the dialect of the capital city. Therefore, it would change if the capital was moved to a different city (SHI 2016, 723). The last two imperial dynasties had their capital in Beijing, thus the Guānhuà (known in English as 'Mandarin') which was the base for the later standard, was built upon the dialects of Northern China, with the Beijing dialect as the core (cf. SHI 2016, 724; Norman 1988, 133; LÜ 2002, 42).

It must also be noted, that in China there existed for centuries two parallel written languages: the classical literary language - wényánwén 文言文, and the vernacular literary language - báihuàwén 白话文. Wényánwén was based on Old Chinese, the language used in the times of the Zhou dynasty, and it had not changed much since ancient times (cf. CHEN 2015, 532). It was the standard written language since the times of Han dynasty until the beginning of the twentieth century (Dong 2014, 80). Báihuàwén started to be used at the end of the Tang dynasty (618-907). It was based on the vernacular used in Northern China. Báihuà 白话 ('colloquial speech') entered the popular, informal literature, and it was much closer to the language spoken by ordinary people than wényánwén (cf. CHEN 2015, 532). 


\section{THE CONCEPT OF GUOYU 国语}

The creation of Modern Standard Chinese started in fact in the mid-19 Century, after the Opium Wars, when China realized that it had to modernize the country as well as the language (cf. CHEN 2004, 13). A country as large as China, with a network of mutually unintelligible dialects and minority languages, required a language reform. It was believed that uniformity of language was necessary for the unity of the country and for future modernization (cf. Chen 2004, 14; Norman 1988, 133; RAMSEY 1987, 3-4).

The idea of creating a Standard Spoken Chinese other than the dialect of the capital city, emerged at the beginning of the $20^{\text {th }}$ Century. The term Guóyú 国语 ('national language') was proposed, borrowed from Japanese. Many students at that time went to Japan and were inspired by the idea of a common standard language. They believed that China could similarly adapt a universal language for the whole nation and they incited the Guóyǔ Yùndòng 国语运动 ('National Language Movement') (CHEN 2004, 14; cf. LÜ 2002, 47-67).

How to create the national language was still a matter of discussion. There were ideas to abolish the Chinese language completely and replace it, for example, by Esperanto. Qian Xuantong (Qián Xuántóng 钱玄同) put this concept forward, arguing that only this way could China be free from the backward past (cf. RAMSEY 1987, 3). This idea was obviously utopian and was not taken up, but the works on a national standard had started.

\section{CONFERENCE ON THE UNIFICATION \\ OF PRONUNCIATION IN 1913 (Dúyinn tǒngyī huǐ 读音统一会)}

On 15 February 1913 the Conference on the Unification of Pronunciation started in Beijing (RAMSEY 1987, 5; LÜ 2002, 54). The work of the language reformers had begun in 1911, when it was decided to form a 'General Committee for the Survey of the National Language' (Guóyǔ Diàochá Zónghuì 国语调查总会). Its task was to conduct large-scale research on the linguistic situation of the country (CHEN 2004, 15-6).

Due to the immense linguistic diversity in China, the task to create a new national language was not easy. The language reform involved also the restructuring of the Chinese writing system, which had developed many variations during the centuries of usage (CHEN 2004, 15). ${ }^{1}$

\footnotetext{
${ }^{1}$ Many of the partakers in the National Language Movement insisted on replacing Chinese characters with a phonetic script (CHEN 2004, 15).
} 
It was not at all obvious which dialect should be the phonological base of the new national standard. Though the language of Beijing, the capital, might have seemed to be the most natural choice, the dialects of Nanjing, Wuhan and Shanghai also had strong advocates. Other scholars suggested that the standard language should not be built on a single dialect, but ought to include universal features (CHEN 2004, 14).

After a long debate on which sounds should be adopted as standard, the North versus the South, the representatives of each province had only one vote. And thus, the Mandarin variety won, as it is spoken in the majority of the country (RAMSEY 1987, 5-8).

After the decision was made to use the Mandarin dialect as the basis of the pronunciation for the new national language, the Committee determined the articulation of 6500 characters, voting on each character separately. This way, the members defined the sound system of Guóyu (CHen 2004, 17; RAMSEY 1987, 8). The results were published six years later in the Dictionary of national pronunciation (Guóyinn Zìdiăn 国音字典) (CHEN 2004, 17).

Despite the fact that the phonology of the newly created standard was based mainly on the pronunciation used in Beijing, there was an ideological belief that it should simultaneously combine characteristics of all dialects. The most salient features were the entering tone (rùsheng 入声), which had disappeared in the Mandarin dialects but still exists in the southern dialects, also the voiced fricative [v] from the $\mathrm{Wu}$ dialects was included, and other features which did not prevail in the northern dialects (CHEN 2004, 18; RAMSEY 1987, 9). Consequently, the proclaimed standard became an artificial language which hardly anybody could speak (CHEN 2004, 18; RAMSEY 1987, 9-10; SHI 2016, 724-5). This tongue was to be later called lăo guóyin 老国 音 — i.e. the 'old national pronunciation' in contrast to the xin guóyin 新国 音 — the 'new national pronunciation,' which was defined in the 1920s.

\section{XIN GUOYIN 新国音 - THE 'NEW NATIONAL PRONUNCIATION'}

In the meantime, the movement to reform written Chinese was very strong. The Báihuàwén Yùndòng 白话文运动 ('The Vernacular Movement') succeeded to promote the vernacular literary language, based on the northern Mandarin languages, as the language of literature, replacing wényánwén, which was incomprehensible to the majority (RAMSEY 1987, 10; DuAnmu 2000, 7; Norman 1988, 134). 
The phonological system presented in the Dictionary of national pronunciation in 1919 was never fully accepted by the language committee and was criticised for its artificiality. Thus, it was decided that instead of creating a language out of many dialects, one single dialect should serve as the basis for pronunciation. Under the influence of the Vernacular Movement, the dialect chosen for this purpose was Béijīnghuà 北京话 — the speech of the capital city (Shi 2016, 725; Chen 2004, 19-20; Norman 1988, 134-5).

In 1932 an official decision was proclaimed by the Ministry of Education that the Beijing Mandarin dialect was to become the model for the xin guóyin. The same year, a revised version of the Dictionary was published Guóyin chángyòng zìhui 国音常用字汇 ('A Glossary of frequently used characters in National Pronunciation') (Norman 1988, 135; Chen 2004, 20).

This dictionary contained 12,219 characters, each of them annotated in a special phonetic alphabet created for the purpose of writing down the pronunciation of Chinese characters - zhùyin fúhào 注音符号, ${ }^{2}$ and with Guóyǔ luómăzì (Gwoyeu romatzyh) 国语罗马字 ('National Language Romanization,3) (CHEN 2004, 20).

The new pronunciation did not include the fifth tone, i.e. the rùshèng, nor any sounds not present in the vernacular of Beijing (CHEN 2004, 20-1). What is known today as the Guoyu, i.e. the Mandarin Standard Chinese in Taiwan, is in principle this new version of the 'National Pronunciation' (SHI 2016, 725).

It is important to note that Guóyú was based on a spoken language, not on the literary wényán form. Before this, the literary language was considered to be prestige. It was not an easy decision to choose a vernacular, a language of lower social status, as the standard for the whole country (cf. CHEN 2004, 21-2).

\section{THE FORMING OF PUTONGHUA}

Soon after the establishment of the People's Republic of China, the government continued the works on one common language for the Chinese nation. In 1955, two conferences were held: the National Conference on Script Reform (Quánguó Wénzi Găigé Huìyi 全国文字改革会议) and the Symposium on the Standardization of Modern Chinese (Xiàndài Hànyǔ

\footnotetext{
${ }^{2}$ For a detailed information of the zhùyinn fúhào (earlier known as zhùyinn zìmú 注音字母) see SHI 2016, 725-6; CHEN 2004, 180-2.

${ }^{3}$ For more information on Guóyǔ luómăzì see CHEN 2004, 182-4.
} 
Guīfànhuà Xuéshù Huìyì 现代汉语规范化学术会议) (CHEN 2004, 23; TAN (ed.) 2000, 198). The focus of these meetings was put on the script reform, but the National Standard was also an important issue (CHEN 2004, 23).

The script reform conducted by the committee for language planning involved regulating the writing system and designing and promoting a new system of transliteration of the Chinese language, i.e. Hànyŭ pinnyīn fäng'àn 汉语拼音方案 ('Phonetic System of the Chinese Language') (cf. SHI 2016, 727). ${ }^{4}$

The xin guóyin played a very significant role in the creation of the present standard Chinese language (cf. CHEN 2004, 21). The pronunciation of the new tongue is in fact a continuation of the 'new national pronunciation', although in the process of establishing the standard there were still some ideas of introducing southern features, such as the distinction between the so-called sharp (jiān 尖) and rounded (tuán 团) consonants (CHEN 2004, 24; SHI 2016, 726).

The name of the standard language proclaimed in 1956 was changed into Pŭtōnghuà 普通話 ('common tongue'), to stress its intended closeness to all the nationalities living in China. The definition of the national common language was given in the "State Council Instruction Concerning Spreading Putonghua” (Zhou 1956, translation by Chen 2004, 24): „Putonghua is the standard form of Modern Chinese with the Beijing phonological system as its norm of pronunciation, and Northern dialects as its base dialect, and looking to exemplary modern works in baihua 'vernacular literary language' for its grammatical norms."

From this moment, Pǔtōnghuà officially became the standard national language of all China (cf. LÜ 2002, 70). The organ which regulates the language is the State Language Commission (Guójiā Yǔyán Wénzì Gōngzuò Wěiyuánhui 国家语言文字工作委员会) (“State Bureaus...” 2014).

\section{THE SOUND SYSTEM OF PUTONGHUA}

The 1956 definition leaves no doubt about the norm of pronunciation for Pǔtōnghuà — it is the Beijing dialect. In fact, as Norman $(1988,138)$ states, phonology "[...] is the only aspect of the modern language that is strictly codified." Both vocabulary and grammar are still lacking firm norms. This may be the outcome of the common belief that Chinese dialects differ

\footnotetext{
${ }^{4}$ For more information on the Hànyŭ pinyyinn system see SHI 2016, 727-9.
} 
mostly in pronunciation, "less in vocabulary, least in syntax (DEFrancIS 1967, 142).

The results of codification are published in the normative Xiàndài Hànyŭ Cídiăn 现代汉语词典 - The Contemporary Chinese Dictionary, which was published for the first time in 1978 and hitherto has had seven editions, the last one in 2016 (cf. ZhongGuo Shehui Kexueyuan... 2002; 2016).

Traditionally, the phonetic system is presented in tables according to the division into initials (shēngmǔ 声母), finals (yùnmǔ 韵母) and tones (shēngdiào 声调). They are usually noted down in Hànyŭ pīnyìn and zhùyīn fúhào annotations, see Tables 1, 2, 3. ${ }^{5}$

Table 1. The initials of Pǔtōnghuà (cf. Zhongguo Shehui Kexueyuan... 2002, 2696;

Quanguo Renda... 2001, 118-9; IPA transcription according to SHI 2016, 728).

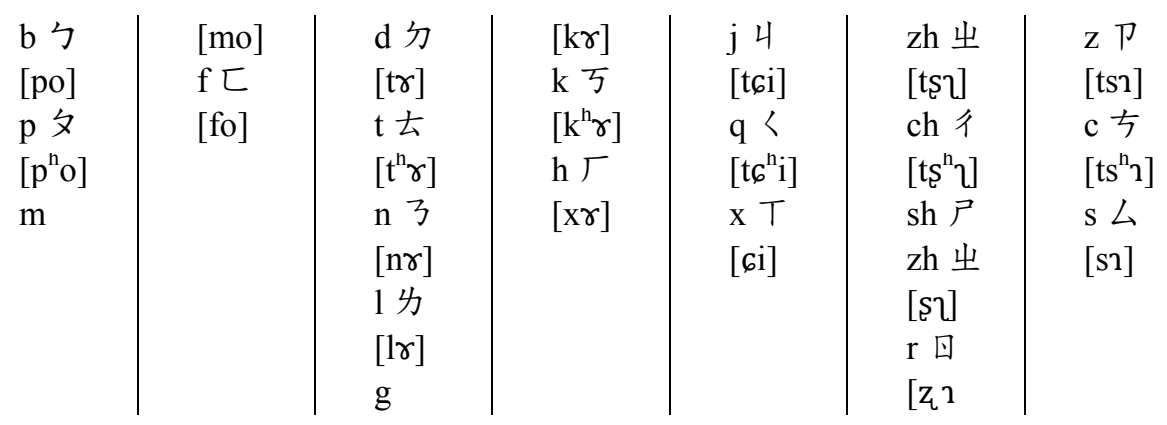

Table 2. The initials of Pǔtōnghuà (cf. Zhongguo Shehui Kexueyuan... 2002, 2697; Quanguo RENDA... 2001, 119-20; IPA transcription according to SHI 2016, 728).

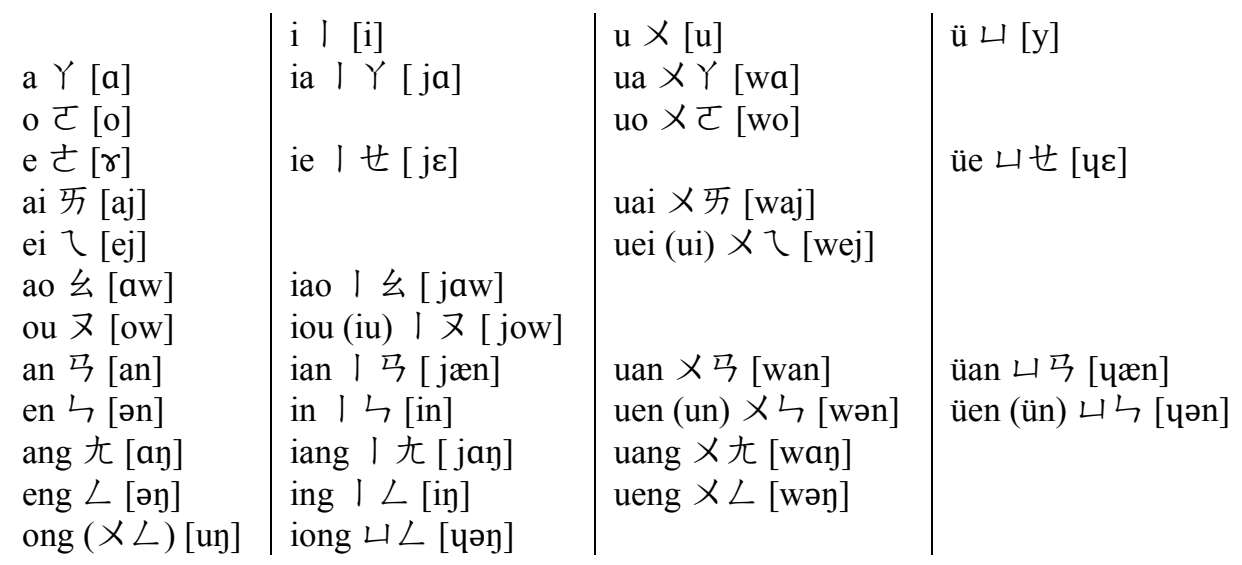

\footnotetext{
${ }^{5}$ For a detailed description of the phonology of Pǔtōnghuà see NORMAN 1988, 138-48; CHEN 2004, 34-7.
} 
Table 3. The tones of Pǔtōnghuà (cf. ZhongguO Shehui KeXUeYuAn... 2002, 2698; CHEN 2004, 36).

\begin{tabular}{l|l|l} 
First tone (high and level) & yìnping 阴平 & 55 \\
\hline Second tone (rising) & yángpíng 阳平 & 35 \\
\hline Third tone (falling-rising) & shàngshēng 上声 & 214 \\
\hline Fourth tone (falling) & qùshēng 去声 & 51
\end{tabular}

\section{DIFFERENCES BETWEEN PUTONGHUA AND THE BEIJING DIALECT}

Although the sound system of the Beijing dialect served as the basis of the national standard, these two phonetic systems are not identical. Not all the features of the speech of the capital city have been included in Pǔtōnghuà. In the language of Beijing there are many local characteristics, which do not appear in the systematized sound inventory of Pǔtōnghuà (cf. TAN (ed.) 2000, 200; CHEN 2004, 37).

San Duanmu $(2002,6)$ lists a few traits which have not been included in the Modern Standard Mandarin from the speech of genuine Pekingeses. There exist some syllables which do not occur in Pǔtōnghuà at all, such as $\left[\mathrm{t}^{\mathrm{h}} \mathrm{en}^{51}\right]$ ('not to hurry when one should'), or syllables which are not pronounced in the same tones, e.g. [ $\left.\mathrm{t}^{\mathrm{w}} \mathrm{ei}\right]$ in the third tone.

More cases of features typical to the Beijing dialect are enumerated by Ping Chen (2004, 37-41). There are, for example, some alterations in the initials. The phenomenon of so-called rhotacization (érhuàyùn 儿化韵) is exceptionally frequent in Běijīnghuà and has been very limited in Pǔtōnghuà (CHEN 2004, 39-40). The use of syllables in the neutral tone is also much more common in the speech of Beijing (CHEN 2004, 40-1).

It is said (cf. WANG et al. 2016), that during the process of standardization of the national language, researchers went to a place called Luanping (Luánpíng 㴒平) near Chengde (Chéngdé 承德) in Hebei Province (Héběi Shěng 河北省) in order to collect phonetic material. Luanping was chosen as a place where the speech was pure, very close to that of Beijing, but simultaneously lacking those features which made Beijing dialect less understandable, such as the very strong rhotacization (WANG et al. 2016: 90). 


\section{EVOLUTION OF THE PRONUNCIATION OF PUTONGHUA}

The codified standard is not changing visibly, despite the absorption of words and expression from other dialects, because these words are usually adapted to the Beijing pronunciation (Duanmu 2002, 5-6). However, due to the promotion of Pǔtōnghuà, it is spreading and there are different varieties of Pǔtōnghuà (Lin 2007; 265-6; SHI 2016, 733). The approved version is found in national radio and TV broadcasts and is used by speakers of Pǔtōnghuà from Beijing who "do not exhibit local features peculiar to the Beijing dialect” (Lin 2007, 265).

One must remember that there are more than one standard Mandarin Chinese. Besides Pǔtōnghuà, Mandarin is spoken in Taiwan, where it is known as Guóyŭ, and in Singapore, as Huáyú 华语. However, there are only some minor differences in the sound system and these standards differ mainly in vocabulary (SHI 2016, 733). ${ }^{6}$

On the other hand, due to the enormous diversity of Chinese languages in

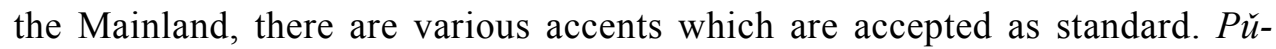
tônghuà is undergoing the process of "vernacularization" (SAILlaRD 2004, 168) and is developing into "local Putonghua" (difāng Pǔtōnghuà 地方普通话), or “non-standard Putonghua” (bù biāozhǔn dì Pǔtōnghuà 不标准的普通话) (cf. CHEN 2004, 41-6).

Local Pǔtōnghuà in Pumen (Pùmén 铺门), a small town in Guangxi Zhuang AR, can serve as one of many examples (ZHANG 2008). The dialect of Pumen (Pùménhuà 铺门话) belongs to the Pinghuà 平话 dialect group, which is one of the smaller dialect groups recognised by Chinese linguists (ZHANG 2008, 74).

There are two kinds of phonological phenomena which can occur. One is that the tones are mostly similar to those of Putonghua, but there are slight differences in initials and finals. The second situation is that the differences in tones, vocabulary, initials and finals are comparatively significant (ZHANG 2008: 74).

To illustrate how Pǔtōnghuà is diversifying, only a few examples will be given below, according to Zhang (2008):

Among initials, $[\mathrm{h}]$ is often read as [f], e.g. 花 is pronounced [fa]; or [ts, $\mathrm{ts}^{\mathrm{h}}, \mathrm{s}$ ] are read as [ts, $\mathrm{ts}^{\mathrm{h}}, \mathrm{s}$ ], e.g. 中 is pronounced [tsuy]. Sometimes the zero initial (ling shēngmú 零声母) is read as [ฤ], e.g. 我 is pronounced [yo] (ZHANG 2008: 74-75).

\footnotetext{
${ }^{6}$ For more information on differences between Pǔtōnghuà, Guóyǔ and Huáyǔ see SHI 2016, 733-735; LiN 2007, 265-74).
} 
Regarding finals, it is quite common that [au] is read as [ou], e.g. 保 is pronounced [bou]. There are also differences in pronouncing the [ə习] final, in Pumen it is read as [an], e.g. 能 is pronounced [nay] (ZHANG 2008, 75).

\section{CONCLUSIONS}

To create a language for the whole people is beyond any doubt a very demanding task. Designing Pǔtōnghuà has been an undertaking that has spanned over a long period of time, starting before the establishment of the People's Republic of China. It has engaged many specialists, linguists and officials in meticulous work. The final choice of the spoken Beijing dialect as the base for its pronunciation was decisive in many aspects, but it should be borne in mind, that Pǔtonghuà is not merely an adaptation of the language of the capital.

In the long process of standardization of the national language in China, pronunciation is thus far the only fully codified aspect. Vocabulary and grammar are still in the course of systematisation. In spite of the intensive promotion of the national standard throughout the country, the approved phonetic system is not influenced by dialects. At the same time, even though its pronunciation is based on one vernacular, Pǔtōnghuà is diversifying in the areas of non-Mandarin dialects, and some alterations are acceptable. And thus, there are many "non-standard" varieties of the standard. However, "pure" Pütōnghuà, which was standardized in the 1950s, is regarded as a language of prestige and it remains officially untouched.

\section{BIBLIOGRAPHY}

Chen, PIng. 2004. Modern Chinese: History and Sociolinguistics. Cambridge: Cambridge University Press.

Chen, Ping. 2015. "Language Reform in Modern China." In William S.-Y. Wang and Chaofen Sun (eds.). The Oxford Handbook of Chinese Linguistics, 531-40. Oxford: Oxford University Press.

Dong, Hongyuan. 2014. A History of the Chinese Language. London and New York: Routledge. Duanmu, San. 2002. The Phonology of Standard Chinese. Oxford: Oxford University Press.

DeFrancis, John. 1967. "Language and Script Reform". In Thomas A. Sebeok (ed.). Current Trends in Linguistics. Vol. 2: Linguistics in East Asia and South East Asia, 130-50. The Hague, Paris: Mouton. 
DeFrancis, John. 1984. The Chinese Language. Fact and Fantasy. Honolulu: University of Hawaii Press.

Lin Yen-HweI. 2007. The Sounds of Chinese. Cambridge: Cambridge University Press.

LÜ JIPING 吕冀平 (ed.). 2002. Dāngqián Wǒguó Yǔyán Wénzì de Guîfànhuà Wèntí 当前我国语言 文字的规范化问题 [The problems of the standardization of modern Chinese language and writing]. Shanghai: Shanghai Jiaoyu Chubanshe.

Norman, Jerry. 1988. Chinese. Cambridge: Cambridge University Press.

Quanguo Renda Jiao Ke Wen Wei WeiYuanhui JiaOyushi Jiaoyubu Yuyanwenzi Yingyong GUANLISI 全国人大教科文卫委员会教育室教育部语言文字应用管理司 [National People's Congress' Education, Science, Culture and Public Health Committee's Education Office and Ministry's of Education Administrative Department of Language Application]. 2001. Zhōnghuá Rénmín Gònghéguó Guójiā Tōngyòng Yǔyán Wénzì FăXuéxí Dúběn 中华人民共和国国 家通用语言文字法学习读本 [A handbook of the People's Republic of China law of the country's common language and writing]. Beijing: Yuwen Chubanshe.

Saillard, Claire. 2004. "On the Promotion of Putonghua in China: How a Standard Language Becomes a Vernacular.” In Minglang Zhou (ed.). Language Policy in the People's Republic of China: Theory and Practice Since 1949, 163-76. Kluwer Academic Publishers.

SHI DingXu. 2016. "Standard Chinese." In Chan Sin-WAi (ed.). The Routledge Encyclopedia of the Chinese Language, 723-35. London, New York: Routledge.

State Bureaus administered By Ministries or Commissions. 2014. China.org.cn. Accessed 24 March 2018. http://www.china.org.cn/china/leadership/2013-03/11/content_28206251.htm.

TAN DAZHENG 谈大正 (ed.). 2000. Hànyǔ de wénhuà tèzhēng yǔ guójiā tōngyòng yǔyán wénzì 汉 语的文化特征与国家通用语言文字 [Cultural characteristics of the Chinese language and the common language and script of China]. Beijing: Zhongguo Fazhi Chubanshe.

WANG, Feng, and Yaching Tsai. 2015. "Chinese writing and literacy." In William S.-Y. Wang and CHAOFEN Sun (eds.). The Oxford Handbook of Chinese Linguistics, 554-64. Oxford: Oxford University Press.

WANG XIAODONG 汪晓东 et al. 2016. "Luán píng: Pǔtōnghuà zuì biāozhǔn dì dìfāng 滦平: 普通 话最标准的地方” [Luanping: the most standard place of Putonghua]. Xiao Kang 小康. Insight China: $90-1$.

YUAN JiAHUA 袁家华. 2003. Hànyǔ fāngyán gàiyào (Dì’èr băn) 汉语方言概要（第二版） [An outline of Chinese dialects (second edition)]. Beijing: Yuwen Chubanshe.

ZHANG JIANQIANG 张建强. 2008. "Pùmén dìfāng pǔtōnghuà yǔyán tèzhēng fēnxī 铺门地方普通 话语言特征分析” [Analysis of the characteristics of Pumen local Putonghua]. Journal of Hezhou University 贺州学院学报 2008年02期: 74-6.

ZHONGGUO SHEHUI KEXUEYUAN YUYAN YANJIUSUO CIDIAN BIANJISHI 中国社会科学院语言研究 所词典编辑室 [The Dictionary Department of the Institute of Linguistics of the Chinese Academy of Social Sciences]. 2002. Xiàndài Hànyǔ Cídiăn (Hàn Yīng Shuāngyǔ) 现代汉语 词典（汉英双语）[The Contemporary Chinese Dictionary (Chinese-English Edition)]. Beijing: Waiyu Jiaoxue yu Yanjiu Chubanshe.

ZHONGGUO SHEHUI KEXUEYUAN YUYAN YANJIUSUO CIDIAN BIANJISHI 中国社会科学院语言研究 所词典编辑室 [The Dictionary Department of the Institute of Linguistics of the Chinese Academy of Social Sciences]. 2016. Xiàndài Hànyǔ Cídiăn. Dì 7 băn 现代汉语词典. 第7版 [The Contemporary Chinese Dictionary. Seventh Edition]. Beijing: Shangwu Yinshuguan.

ZHOU ENLAI 周恩来. 1956. “Guówùyuàn guānyú tuīguăng Pǔtōnghuà de zhǐshì 国务院关于推广 普通话的指示” [State Council Instructions concerning the Spreading of Putonghua]. The Central People's Government of the People's Republic of China. Accessed 12 September 2018. http://www.gov.cn/test/2005-08/02/content_19132.htm. 


\section{JAK STWORZYĆ JĘZYK DLA WSZYSTKICH LUDZI? \\ O KODYFIKACJI WYMOWY PUTONGHUA}

\section{Streszczenie}

Proces tworzenia nowoczesnego języka narodowego dla całych Chin był długi. Zaczął się na początku XX wieku, kiedy stało się jasne, że potrzebny jest wspólny język, by zjednoczyć Chińczyków. W ten sposób powstała koncepcja Guóyǔ — ,języka narodowego”.

Po założeniu Chińskiej Republiki Ludowej prace zostały wznowione, standard został przemianowany na Pǔtōnghuà — „wspólną mowę”. Jego wymowa opiera się na dialekcie Pekinu, dialekty mandaryńskie były źródłem leksyki, a gramatykę oparto na „modelowych pracach w báihuă”.

Jak jednak dokładnie wyglądały prace nad stworzeniem nowego standardu? Ten artykuł ma na celu pokazanie procesu kodyfikacji wymowy tego, co obecnie znamy jako Pŭtōnghuà. Dlaczego postanowiono wybrać mowę Pekinu jako punkt wyjścia, jak przebiegały prace, a także jak zmieniał się sam standard?

Słowa kluczowe: Putonghua; mandaryński; kodyfikacja; reforma językowa; fonetyka; fonologia. 